\title{
Humanitarian law, human rights law and the bifurcation of armed conflict
}

Article

Accepted Version

Hill-Cawthorne, L. (2015) Humanitarian law, human rights law and the bifurcation of armed conflict. International and Comparative Law Quarterly, 64 (2). pp. 293-325. ISSN 14716895 doi: https://doi.org/10.1017/S002058931500010X Available at https://centaur.reading.ac.uk/39403/

It is advisable to refer to the publisher's version if you intend to cite from the work. See Guidance on citing.

To link to this article DOI: http://dx.doi.org/10.1017/S002058931500010X

Publisher: Cambridge University Press

All outputs in CentAUR are protected by Intellectual Property Rights law, including copyright law. Copyright and IPR is retained by the creators or other copyright holders. Terms and conditions for use of this material are defined in the End User Agreement.

\section{www.reading.ac.uk/centaur}

\section{CentAUR}

Central Archive at the University of Reading

Reading's research outputs online 


\title{
HUMANITARIAN LAW, HUMAN RIGHTS LAW AND THE BIFURCATION OF ARMED CONFLICT
}

\author{
Lawrence Hill-Cawthorne*
}

\begin{abstract}
This article offers a fresh examination of the distinction drawn in international humanitarian law (IHL) between international and non-international armed conflicts. In particular, it considers this issue from the under-explored perspective of the influence of international human rights law (IHRL). It is demonstrated how, over time, the effect of IHRL on this distinction in IHL has changed dramatically. Whereas traditionally IHRL encouraged the partial elimination of the distinction between types of armed conflict, more recently it has been invoked in debates in a manner that would preserve what remains of the distinction. By exploring this important issue, it is hoped that the present article will contribute to the ongoing debates regarding the future development of the law of non-international armed conflict.
\end{abstract}

Key words: international humanitarian law; international human rights law; noninternational armed conflict; distinction between international and noninternational armed conflict.

\section{INTRODUCTION}

International lawyers have long been preoccupied with the issue of conflict characterisation. Thus, Soviet presence in Afghanistan from 1979 raised questions regarding the correct classification of the conflicts in that country for the purposes of international law. ${ }^{1}$ Similarly, the complexities arising from the collapse of the Socialist Federal Republic of Yugoslavia created great confusion over the character of the conflicts in that region. ${ }^{2}$ Disagreement also existed over the nature of the conflicts in Afghanistan (following the 2001 invasion) and Iraq (following the 2003 invasion), due to the regime changes that occurred in those countries. ${ }^{3}$ These issues also arose when the Security Council authorised foreign intervention in Libya in $2011 .^{4}$

\footnotetext{
* Lecturer in Law, University of Reading, 1.hill-cawthorne@ reading.ac.uk. I am very grateful to Professor Mads Andenas, Professor Susan Breau, Dr James A Green, Dr Martins Paparinskis and especially Professor Dapo Akande for comments on earlier drafts. Thanks are also due to Professor Malcolm Evans and the anonymous reviewers for their feedback. Some of the themes discussed in this article were the subject of a presentation by the author at a Public International Law Research Seminar at All Souls College, Oxford in 2013. I am grateful for the comments received there. The views expressed as well as any errors or omissions are the responsibility of the author alone.

1 WM Reisman and J Silk, 'Which Law Applies to the Afghan Conflict?' (1988) 82 AJIL 459.

2 For different views on this, see, eg, Prosecutor v Duško Tadić, 15 July 1999, Appeals Judgment, IT-941-A, [83]-[162]; T Meron, 'Classification of Armed Conflict in the Former Yugoslavia: Nicaragua's Fallout' (1998) 92 AJIL 236; C Greenwood, 'International Humanitarian Law and the Tadic Case' (1996) 7 EJIL 265; T Meron, 'International Criminalization of Internal Atrocities' (1995) 89 AJIL 554.

MN Schmitt, 'Iraq (2003 onwards)' in E Wilmshurst (ed), International Law and the Classification of Conflicts (OUP 2012); FJ Hampson, 'Afghanistan 2001-10' in ibid; A Roberts, 'The End of Occupation: Iraq 2004' (2005) 54 ICLQ 27.

4 UN Security Council Resolution 1973, S/Res/1973 (2011) (17 March 2011). On the contested character of this conflict, see S Sivakumaran, The Law of Non-International Armed Conflict (OUP 2012) 224-5; K Mačák
} 
Such questions arise because the manner in which international law regulates a conflict varies depending on the conflict's character. In essence, international humanitarian law (IHL) bifurcates the concept of armed conflict into two legal categories, expressed in their modern form in common Articles 2 and 3 of the 1949 Geneva Conventions. ${ }^{5}$ Whilst common Article 2 states that the Conventions apply in armed conflicts 'between two or more of the High Contracting Parties' ('international armed conflicts'), ${ }^{6}$ the single common Article 3 sets out the entire regime applicable under the Conventions in 'armed conflict[s] not of an international character' ('non-international armed conflicts'). ${ }^{7}$ Although marking the first treaty provision explicitly designed for non-international armed conflicts, ${ }^{8}$ and thus reflecting an important development in IHL, the brevity of common Article 3 demonstrates the extremely limited degree to which such conflicts have traditionally been regulated by international law relative to inter-State wars. ${ }^{9}$ It is on this basis that most criticisms of the distinction between the two categories of conflict are made, for victims of internal conflicts have enjoyed fewer protections under IHL than those of international conflicts. ${ }^{10}$ This is especially worrying, given that, in the post-1945 period, non-international armed conflicts have become the norm rather than the exception. ${ }^{11}$

Subsequent developments have gradually narrowed the distinction between international and non-international armed conflicts. Importantly, two Additional Protocols to the Geneva Conventions were adopted in 1977, the first further codifying rules applicable in international conflicts, ${ }^{12}$ and the second doing the same for non-international conflicts. ${ }^{13}$ Additional Protocol II (APII), however, contains only fifteen substantive articles, compared with over seventy in Additional Protocol I (API). Moreover, in contrast to common Article 3, which applies to all non-international armed conflicts, APII applies only to non-international conflicts that are fought between a State and those non-State groups that, 'under responsible command, exercise such control over a part of its [the State's] territory as to enable them to carry out sustained and concerted military operations' and to implement the Protocol. ${ }^{14}$ In addition to these developments in APII, Article 1(4) API lifted 'armed conflicts in which

and N Zamir, 'The Applicability of International Humanitarian Law to the Conflict in Libya' (2012) Intl Comm L Rev 403.

5 Geneva Convention for the Amelioration of the Condition of the Wounded and Sick in Armed Forces in the Field (adopted 12 August 1949, entered into force 21 October 1950) 75 UNTS 31 (GCI); Geneva Convention for the Amelioration of the Condition of the Wounded, Sick and Shipwrecked Members of the Armed Forces at Sea (adopted 12 August 1949, entered into force 21 October 1950) 75 UNTS 85 (GCII); Geneva Convention Relative to the Treatment of Prisoners of War (adopted 12 August 1949, entered into force 21 October 1950) 75 UNTS 135 (GCIII); Geneva Convention Relative to the Protection of Civilian Persons in Time of War (adopted 12 August 1949, entered into force 21 October 1950) 75 UNTS 287 (GCIV).

6 GCI-IV, ibid, art 2.

7 GCI-IV (n 5), art 3, chapeau. The category of 'non-international armed conflict' has come to be seen as comprising various sub-categories: J Pejić, 'The Protective Scope of Common Article 3: More Than Meets the Eye' (2011) 93 IRRC 189, 193-5.

8 L Moir, The Law of Internal Armed Conflict (CUP 2002) 30.

9 E Crawford, The Treatment of Combatants and Insurgents under the Law of Armed Conflict (OUP 2010) 1.

10 See, eg, A Duxbury, 'Drawing Lines in the Sand - Characterising Conflicts for the Purposes of Teaching International Humanitarian Law' (2007) 8 Melb J Intl L 259, 268-71; Crawford (n 9) 2.

11 NP Gleditsch et al, 'Armed Conflict 1946-2001: A New Dataset' (2002) 39 J Peace Research 615, cited in Crawford (n 9) 14 (fn 30-1).

12 Protocol Additional to the Geneva Conventions of 12 August 1949, and Relating to the Protection of Victims of International Armed Conflicts (adopted 8 June 1977, entered into force 7 December 1978) 1125 UNTS 3 (API).

13 Protocol Additional to the Geneva Conventions of 12 August 1949, and Relating to the Protection of Victims of Non-International Armed Conflicts (adopted 8 June 1977, entered into force 7 December 1978) 1125 UNTS 609 (APII).

14 APII, ibid, art 1(1). 
peoples are fighting against colonial domination and alien occupation and against racist regimes in the exercise of their right of self-determination' out of the category of noninternational conflicts and brought them under the umbrella of international armed conflicts. ${ }^{15}$

Finally, the law applicable in non-international armed conflicts has continued to develop under both conventional and customary law since the adoption of the Additional Protocols. Regarding conventional law, a number of weapons treaties apply equally in all armed conflicts (and in peacetime). ${ }^{16}$ At the level of custom, it has increasingly been argued that a large number of the rules designed for international armed conflicts now apply equally in non-international conflicts, most notably by the International Criminal Tribunal for the former Yugoslavia (ICTY) and the International Committee of the Red Cross (ICRC). ${ }^{17}$

These developments notwithstanding, important differences remain between the law applicable in international and non-international armed conflicts, and States have consistently expressed their desire to preserve the general distinction. ${ }^{18}$ Indeed, as a caveat to its finding that certain rules previously applicable only in international conflicts now apply under custom in non-international conflicts, the ICTY confirmed that 'only a number of rules and principles governing international armed conflicts have gradually been extended to apply in internal conflicts' and that 'this extension has not taken place in the form of a full and mechanical transplant of those rules to internal conflicts; rather, the general essence of those rules, and not the detailed regulation they may contain, has become applicable to internal conflicts'. 19

It is on this distinction in IHL between international and non-international armed conflicts that the present article focuses. In particular, it examines this issue from the perspective of the influence of international human rights law (IHRL). It will be demonstrated that the evolution of the distinction drawn in IHL between types of conflict has been heavily influenced by the parallel development of IHRL. As such, the approach adopted here differs from that in other accounts of the distinction, which tend to focus on its consequences for victims of non-international conflicts, ${ }^{20}$ or its unsuitability for practical application. ${ }^{21}$ It will be shown in this article that human rights law has had two, seemingly contradictory, effects on this distinction in IHL. Section 2 will demonstrate how the

15 Such conflicts previously were considered non-international in character: D Schindler, 'The Different Types of Armed Conflicts According to the Geneva Conventions and Protocols' (1979) 163 Recueil des Cours $117,133$.

16 See, eg, Convention on the Prohibition of the Development, Production and Stockpiling of Bateriological (Biological) and Toxin Weapons and on their Destruction (adopted 10 April 1972, entered into force 26 March 1975) 1015 UNTS 163.

17 Regarding the ICTY, see Prosecutor v Duško Tadić (Decision on the Defence Motion for Interlocutory Appeal on Jurisdiction) ICTY-94-1 (2 October 1995) [127]. Regarding the ICRC, see J-M Henckaerts and L Doswald-Beck, Customary International Humanitarian Law Volumes I \& II: Rules \& Practice (CUP 2005).

18 See, eg, Rome Statute of the International Criminal Court (adopted 17 July 1998, entered into force 1 July 2002) 2187 UNTS 3 (arts 8(2)(a) and (b) give the Court jurisdiction over specific war crimes committed in international conflicts, whilst the much shorter arts $8(2)(\mathrm{c})$ and (e) relate to war crimes in non-international conflicts).

19 Tadić (n 17) [126].

20 See, eg, L Lopez, 'Uncivil Wars: The Challenge of Applying International Humanitarian Law to Internal Armed Conflicts' (1994) 69 NYU L Rev 916; Duxbury (n 10); D Fleck, 'The Law of Non-International Armed Conflicts' in D Fleck (ed), The Handbook of International Humanitarian Law (OUP 2008) 611-13; Crawford (n 9); K Mastorodimos, 'The Character of the Conflict in Gaza: Another Argument Towards Abolishing the Distinction between International and Non-International Armed Conflicts' (2010) 12 Intl Comm L Rev 437, 464-5.

21 See, eg, JG Stewart, 'Towards a Single Definition of Armed Conflict in International Humanitarian Law: A Critique of Internationalized Armed Conflict' (2003) 85 IRRC 313; D Wilmott, 'Removing the Distinction between International and Non-International Armed Conflict in the Rome Statute of the International Criminal Court' (2004) 5 Melb J Intl L 196; Mastorodimos, ibid. 
emergence of IHRL following the Second World War contributed to the necessary foundation for the incorporation into treaty law of rules regulating non-international armed conflicts. In so doing, an important challenge will be made to conventional accounts which view the postwar developments in IHRL and IHL as entirely separate matters. ${ }^{22}$ Section 2 will also demonstrate how the subsequent expansion of IHRL continued to influence the development of the law of non-international armed conflict. Importantly, these developments have occurred primarily by drawing on the rules previously applicable only in international armed conflicts, such that human rights law has encouraged the gradual elimination of the distinction between types of conflict in IHL. Section 3 will then show how, more recently, human rights law has had the opposite effect, being invoked as a basis for preserving what remains of the distinction. This will be demonstrated with reference to recent debates regarding the development of the law of non-international armed conflict, which invoke IHRL in a very different manner than traditionally was the case.

The aim of this article is to construct a narrative, tracing the development of this distinction in contemporary IHL by contextualising it within broader developments in international law. This narrative will demonstrate that a fundamental shift has occurred in the influence of human rights law on IHL's distinction between categories of conflict. Moreover, it will show how two major topics at the heart of many current debates in the area, those regarding the distinction in IHL and the relationship between IHL and human rights law, are very closely linked. It is hoped that, by tracing and analysing these developments, a richer understanding of this structural feature of IHL will be offered, which can then contribute to the ongoing debates about the future development of the law of non-international armed conflict.

\section{The DisSolution OF THE Distinction BeTweEn CATEGORIES OF ARMED CONFLICT}

The evolution of IHRL following the Second World War played an important role as a catalyst in the development of the law of non-international armed conflict. Importantly, as will be shown in this section, human rights law has been invoked so as to encourage the extension of many of the rules traditionally applicable only in international armed conflicts to their non-international counterparts. The consequence has been the gradual and partial elimination of the distinction between the two categories of conflict in IHL. To demonstrate this, a brief discussion of the distinction as it existed in international law before the consolidation of IHRL is first necessary in section A. This will provide important context for understanding the relevance of IHRL for the adoption of common Article 3 in 1949. Section B will then build upon that discussion by demonstrating how the continued evolution of IHRL has encouraged the subsequent development of the law of non-international armed conflict and narrowing of this distinction in IHL.

\section{A. The traditionally inter-State nature of international law}

Appreciating the origins of the distinction between international and non-international armed conflicts is important for understanding the influence of IHRL. Until the adoption of the four Geneva Conventions in 1949, the distinction arose from the fact that treaty law was generally concerned only with conflicts between States and did not regulate civil conflicts within a

22 See, eg, R Kolb, 'The Relationship between International Humanitarian Law and Human Rights Law: A Brief History of the 1948 Universal Declaration of Human Rights and the 1949 Geneva Conventions' (1998) 38 IRRC 409. 
State. ${ }^{23}$ Although there have long existed customary rules on the laws of war, the project of codifying those rules in multilateral treaties did not begin until the mid-nineteenth century. ${ }^{24}$ At this point in history, international law was presumed to regulate only the reciprocal relationships between States, and treaties generally dealt only with questions relevant to this subject matter; intra-State issues tended to be excluded, as these were seen as belonging to the realm of domestic, as opposed to international law. ${ }^{25}$ Early treatises confirmed this interState focus of traditional international law, with the first editions of Oppenheim containing the classic formulation: 'International Law is a law between States only and exclusively'. ${ }^{26}$ The Oppenheim formula certainly glossed over many of the nuances concerning the position of non-State actors within international law at the time, and one might note here as examples the international minimum standard on the treatment of aliens and direct access of individuals to international tribunals. However, as a formal description, it was for the most part accurate, for whilst individuals were directly engaged by international law in these areas, the principal relationship at issue remained inter-State. ${ }^{27}$ Thus, the international minimum standard concerned the treatment of foreign nationals, ${ }^{28}$ whilst individual access to international tribunals was generally restricted to claims against a foreign State. ${ }^{29}$ This helps to explain why, with the adoption of the early conventions on IHL, the question of their application to civil (intra-State) conflict did not arise. ${ }^{30}$ Instead, they were generally applicable only in

23 See, eg, 1868 Declaration Renouncing the Use, in Time of War, of Explosive Projectiles under 400 Grammes Weight (adopted 11 December 1868, entered into forced 11 December 1868) 138 CTS (1868-9) 2979 (French) [6] ('[t]he Contracting Parties engage mutually to renounce, in case of war among themselves ...'); 1899 Hague Convention (II) with Respect to the Laws and Customs of War on Land with Annex: Regulations respecting the laws and customs of war on land (adopted 29 July 1899, entered into force September 1900) 187 CTS (1898-9) 429-43, art 2 ('[t]he provisions contained in the Regulations ... are only binding on the Contracting Powers, in case of war between two or more of them').

24 Y Dinstein, The Conduct of Hostilities under the Law of International Armed Conflict $\left(2^{\text {nd }}\right.$ edn, CUP 2010) 14. Note, however, certain bilateral treaties before that period included provisions relating to the conduct of hostilities, such as the 1785 Treaty of Amity and Commerce between the United States and Prussia: see A Roberts and R Guelff, Documents on the Laws of War ( $3^{\text {rd }}$ edn, OUP 2000) 4.

25 For an excellent historical assessment of the origins of the inter-State nature of international law, see $\mathrm{K}$ Parlett, The Individual in the International Legal System (CUP 2011) 10-16.

26 L Oppenheim, International Law, A Treatise: Volume II, War and Neutrality (Longmans, Green \& Co 1906) 266. Similarly, see J Westlake, Chapters on the Principles of International Law (CUP 1894) 1 ('[i]nternational law is the body of rules prevailing between states').

27 There were rare exceptions to this, for example, in the case of minority protection, which has a long pedigree in international law, albeit being defined differently over time: $\mathrm{P}$ Thornberry, International Law and the Rights of Minorities (OUP 1991); JE Nijman, 'Minorities and Majorities' in B Fassbender and A Peters (eds), The Oxford Handbook of the History of International Law (OUP 2012).

${ }_{28} \mathrm{AH}$ Roth, The Minimum Standard of International Law Applied to Aliens (AW Sijthoff's Uitgeversmaatschappij NV, Leiden 1949) 23 ('[c]ontrary to the national, whom we have discovered to be practically at the mercy of his own State, the alien enjoys a much more favourable situation').

29 See, eg, MO Hudson, 'The Central American Court of Justice' (1932) 26 AJIL 759, 765; E Borchard, 'The Access of Individuals to International Courts' (1930) 24 AJIL 359; M Paparinskis, The International Minimum Standard and Fair and Equitable Treatment (OUP 2013) 34-6.

30 Similarly, see Y Sandoz, C Swinarski and B Zimmerman (eds), Commentary on the Additional Protocols of 8 June 1977 to the Geneva Conventions of 12 August 1949 (ICRC/Martinus Nijhoff 1987) [4342]; E Crawford, 'Unequal Before the Law: The Case for the Elimination of the Distinction between International and Non-International Armed Conflicts' (2007) 20 Leiden J Intl L 441, 443-4; R Bartels, 'Timelines, Borderlines and Conflicts: The Historical Evolution of the Legal Divide Between International and Non-International Armed Conflicts' (2009) 91 IRRC 35, 47-8; D Kretzmer, 'Rethinking Application of IHL in Non-International Armed Conflicts' (2009) 42 Isr L Rev 8, 11-13; D Akande, 'Classification of Armed Conflicts: Relevant Legal Concepts' in E Wilmshurst (ed), International Law and the Classification of Conflicts (OUP 2012) 32-3. 
situations of 'war', 31 which did not include conflicts between States and their subjects: ' $[\mathrm{t}] \mathrm{o}$ be considered war, the contention must be going on between States'. ${ }^{32}$

The nineteenth century did, however, witness the emergence in customary international law of the doctrines of insurgency and belligerency that addressed, to differing degrees, civil war. ${ }^{33}$ The effectiveness of these doctrines, however, still remained constrained by the interState focus of international law. In particular, they tended to be relevant mainly to those internal conflicts that affected the interests of third States, being invoked by such States to regulate their relations with the parties to the conflict. ${ }^{34}$ Moreover, even according to the doctrine of belligerency, whereby insurgents could be recognised as belligerents either by the State against which they were fighting (leading to the application of the ius in bello between them) or by a third State (leading to the application of the law of neutrality), recognition remained entirely at the discretion of the particular State. ${ }^{35}$ Humanitarian concerns were, therefore, somewhat side-lined. Indeed, recognition of belligerency fell into desuetude in the twentieth century, and it was the refusal by States in particularly atrocious civil wars, such as that in Spain, to recognise the belligerent status of their opponents, which highlighted the need for a more robust method by which to regulate these conflicts; the consequence was a renewed demand, particularly by the ICRC, for treaty rules in this area. ${ }^{36}$

It was, therefore, only in 1949 that non-international armed conflicts explicitly became subject to treaty-based regulation under common Article 3. At the same time, the distinction between international and non-international conflicts was codified. As the first treaty provision adopted to address non-international conflicts, common Article 3 was one of a number of developments at that time that reflected the expansion of the subject matter of international law to include purely intra-State matters. The other key development in this regard was, of course, the emergence of IHRL following the end of the Second World War, reflected in provisions of the Charter of the United Nations, ${ }^{37}$ the 1948 Universal Declaration of Human Rights (UDHR), ${ }^{38}$ and the 1948 Convention on the Prevention and Punishment of the Crime of Genocide. ${ }^{39}$ Lea Brilmayer has opined that these post-war developments represented a shift in international law from traditional contractual notions of legal obligation to the rise of non-reciprocal 'pledges' by States to act in conformity with moral precepts. ${ }^{40}$

31 See above, $\mathrm{n}$ 23. It is noteworthy that a few of the earliest IHL treaties were silent with regard to their scope of application, and certain authorities used this as a basis for arguing that they applied equally in internal conflicts: Sivakumaran (n 4) 30-1.

32 Oppenheim (n 26) 58 (emphasis in original; footnotes omitted). Similarly, see R Phillimore, Commentaries upon International Law: Volume III (T \& JW Johnson \& Co 1857) 67.

33 SC Neff, War the Law of Nations: A General History (CUP 2005) 258-75.

34 RA Falk, 'Janus Tormented: The International Law of Internal War' in JN Rosenau (ed), International Aspects of Civil Strife (Princeton University Press 1964) 208. See also AP Higgins (ed), Hall's Treatise on International Law $\left(8^{\text {th }}\right.$ edn, Clarendon Press 1924) 39.

35 There was some disagreement as to whether States were bound to recognise belligerency, although a consensus seems to have arisen for the view that it was within the discretion of the State: Neff (n 33) 264-6; WE Hall, A Treatise on International Law ( $3^{\text {rd }}$ edn, Clarendon Press 1890) 34; H Lauterpacht, Recognition in International Law (CUP 1947) 246.

36 Moir (n 8) 19-21.

37 Charter of the United Nations and Statute of the International Court of Justice (adopted 26 June 1945, entered into force 24 October 1945) 892 UNTS 119, art 1(3).

38 UNGA Res 217 A(III) (10 December 1948). Although non-binding, the UDHR had important 'moral authority': H Lauterpacht, 'The Universal Declaration of Human Rights' (1948) 25 BYIL 354, 370-5.

39 Convention on the Prevention and Punishment of the Crime of Genocide (adopted 9 December 1948, entered into force 12 January 1951) 78 UNTS 277.

40 L Brilmayer, 'From "Contract" to "Pledge": The Structure of International Human Rights Agreements" (2007) 77 BYIL 163. Others have similarly noted the non-traditional structure of human rights obligations: GG Fitzmaurice, 'The Law and Procedure of the International Court of Justice 1951-4: Treaty Interpretation and Other Treaty Points' (1957) 33 BYIL 203, 277; B Simma, 'From Bilateralism to Community Interest in 
Importantly, these 'pledges' were intra-State in the strictest sense, in that the obligations thereunder rested on States vis-à-vis their own nationals (and, of course, non-nationals within their jurisdiction). The novelty therefore laid in the absence of any necessary inter-State element, in contrast to those previous developments in international law noted above that directly engaged individuals, such as the minimum standard of treatment of aliens. ${ }^{41}$

We might think of these developments in the aftermath of the Second World War as the consolidation of intra-State structures of obligation in international law. By this is meant the general extension of the subject matter of international law to include purely intra-State matters. As seen from the references above to Oppenheim and other early texts, such intraState structures of obligation were generally absent from classical international law, accounting, in large part, for the lack of treaty rules on non-international armed conflicts. The adoption of common Article 3 in 1949 must, therefore, be seen as part of this broader trend in international law, with the emergence of intra-State obligations contributing to the necessary foundations for the adoption of a treaty provision on non-international armed conflicts. The premise underpinning both IHRL and the law of non-international armed conflict is, after all, that it is the relationship between a State and its nationals that is to be regulated. ${ }^{42}$ Indeed, Theodor Meron has highlighted this close relationship between the post-war emergence of human rights law and the adoption of common Article 3:

This Article [common Article 3] is a clear demonstration of the influence of human rights law on humanitarian law. The inclusion in the United Nations Charter of the promotion of human rights as a basic purpose of the Organization, the recognition of crimes against humanity as international crimes, the conclusion of the 1948 Genocide Convention and the regulation by a multilateral treaty of non-international armed conflicts for the first time in 1949, all stemmed from this influence. $^{43}$

The novelty of these broader developments, however, meant that common Article 3 would prove the most contentious article during the 1949 diplomatic conference. ${ }^{44}$ Importantly, many of the debates on what would become common Article 3 were concerned not so much with extending humanitarian law to internal conflicts but rather, more generally, with extending international law to intra-State matters. This is evidenced by the records of the

International Law' (1994) 250 Recueil des Cours 217, 242-3; J Crawford, 'Multilateral Rights and Obligations in International Law' (2006) 319 Recueil des Cours 325. The International Court of Justice soon recognised the non-traditional character of the obligations under the Genocide Convention: Reservations to the Convention on the Prevention and Punishment of the Crime of Genocide, Advisory Opinion [1951] ICJ Rep 15, 23.

41 As noted above, however, certain earlier developments in specialised fields did, to different degrees, address intra-State relationships, such as the rules on the protection of minorities in particular States: see above, $\mathrm{n} 27$. The post-1945 developments were, however, still unique in their attempt to lay down general human rights standards to apply to all States.

42 H Krieger, 'A Conflict of Norms: The Relationship between Humanitarian Law and Human Rights Law in the ICRC Customary Law Study' (2006) 11 JCSL 265, 275; Kretzmer (n 30) 9. Admittedly, the growth of the category of 'non-international armed conflict' has seen a number of examples that do not fit this model, such as those involving two more non-State armed groups, with no central government involvement: see Pejić (n 7).

43 T Meron, The Humanization of International Law (Martinus Nijhoff 2006) 7 (footnotes omitted). Whilst Meron also refers to the prosecution of crimes against humanity, at the time these could only be prosecuted where linked to an inter-State conflict: E Schwelb, 'Crimes Against Humanity' (1946) 23 BYIL 178, 207; A Cassese, International Criminal Law (2 ${ }^{\text {nd }}$ edn, OUP 2008) 104.

44 B de Schutter and C Van Der Wyngaert, 'Coping with Non-International Armed Conflicts: The Borderline Between National and International Law' (1983) 13 Ga J Intl \& Comp L 279, 284 (noting that common art 3 was the most debated provision at the conference). 
comments of the delegation of Burma, unofficial representative of the Asian bloc, ${ }^{45}$ which objected to the inclusion of any provision relating to non-international armed conflicts. ${ }^{46} \mathrm{~A}$ central concern of the Burmese delegate was that '[i]nternal matters cannot be ruled by international law or Conventions ... It is not the object of the Conference to intervene in matters essentially within the domestic jurisdiction of any State. ${ }^{47}$ Such objections did not prevail, however, largely because they ignored the contemporaneous developments noted above. Indeed, in response to similar objections by the $\mathrm{UK},{ }^{48}$ the Soviet delegate made clear the importance of recent innovations in laying the foundation for the adoption of common Article 3:

This theory [that international law does not regulate internal matters] was not convincing, since although the jurists themselves were divided in opinion on this point, some were of the view that civil war was regulated by international law. Since the creation of the Organization of the United Nations, this question seemed settled. Article 2 of the Charter provided that Member States must ensure peace and world security. They could therefore not be indifferent to the cessation of hostilities, no matter the character or localization of the conflict. Colonial and civil wars therefore came within the purview of international law. ${ }^{49}$

The post-war consolidation of intra-State structures of obligation thus played an important role in the adoption of common Article 3. In this sense, although it is true that, generally, there was no cross-fertilisation between IHL and IHRL at this time ${ }^{50}$ there was an important structural relationship between IHRL and the law of non-international armed conflict. ${ }^{51}$ As reflected in the quote above by Meron, these post-war developments in IHL and IHRL were not merely coincidental but intimately connected. The extension of international law to purely intra-State matters rendered anachronistic the historical basis for differentiating between international and non-international conflicts.

Importantly for the present thesis, common Article 3 was based on the proposed (but eventually unsuccessful) preamble to the Geneva Conventions. ${ }^{52}$ The new treaty law of noninternational armed conflict was, therefore, modelled on the law applicable in international armed conflicts, with the result that, whilst codifying the distinction, the Geneva Conventions partially narrowed it. Indeed, this provenance of common Article 3 helps to explain why it lays down only the most basic and open-ended norms. Of course, the uniqueness of these broader developments in international law meant that any provision regarding internal

45 DA Elder, 'The Historical Background of Common Article 3 of the Geneva Conventions of 1949' (1979) 11 Case W Res J Intl L 37, 50 (referring to Burma as the 'self-styled Asian representative' at the 1949 diplomatic conference).

46 The main objections of Burma to what became common art 3 can be found in Final Record of the Diplomatic Conference of Geneva of 1949: Volume II, Section B (ICRC 1963) at 327-30.

47 Ibid, 330

48 Ibid, 10.

49 Ibid, 14.

50 Kolb (n 22).

51 Similarly, see Kretzer (n 30) 9.

52 JS Pictet (ed), Commentary to Geneva Convention I for the Amelioration of the Condition of the Wounded and Sick in Armed Forces in the Field (ICRC 1952) 23. A brief look at some of the proposals for the preambles reveals their similarity to common art 3: see, eg, Final Record of the Diplomatic Conference of Geneva of 1949: Volume II, Section A (ICRC 1963) 366 (Soviet Union); Final Record of the Diplomatic Conference of Geneva of 1949: Volume I (ICRC 1963) 113 (Stockholm draft). 
conflicts was necessarily going to be very limited, as many States were concerned as to the consequence that legislating for such conflicts would have on their sovereignty. ${ }^{53}$

Following these initial developments in the wake of the Second World War, the subsequent evolution of IHRL has continued to encourage the parallel development of the law applicable in non-international armed conflicts. As with the adoption of common Article 3 , the consequence of these developments has been a further reduction in the distinction drawn by IHL between types of armed conflict. It is to this that we now turn in the following section.

\section{B. The expansion of the law of non-international armed conflict}

In the decades following the adoption of the first international human rights instruments in the aftermath of the Second World War, IHRL developed considerably, marked by the widespread ratification of international and regional human rights treaties. ${ }^{54}$ This rapid evolution of IHRL in turn both represents and has encouraged the continued expansion of international law from its historically inter-State domain, with the result that it now concerns itself more than ever with intra-State matters and, more specifically, the protection of the individual. As the International Law Association's Committee on International Human Rights Law and Practice has stated, '[t]he permeation of international human rights law through general international law constitutes a quiet revolution which invariably targets international law's most "statist" features'. ${ }^{55}$ More specifically, individual protection, without regard to any necessary inter-State element, now forms a major substantive area of international legal regulation. Whilst a number of scholars have cautioned against overstating the implications of this trend, its existence is undeniable. ${ }^{56}$ Indeed, one can see this impact of IHRL in many diverse areas, from the methodological approach to the formation of custom, ${ }^{57}$ to the debates regarding the need to introduce human rights considerations into the structure of the

53 See, eg, Final Record: Vol II-B (n 46) 10 (UK) and 98-9 (France). Sovereignty concerns would continue to be expressed in subsequent conferences: Official Records of the Diplomatic Conference on the Reaffirmation and Development of International Humanitarian Law Applicable in Armed Conflicts, Geneva (1974-7): Volume VIII (Federal Political Department 1978) 205 (Argentina); ibid, 206 (German Democratic Republic); Official Records of the Diplomatic Conference on the Reaffirmation and Development of International Humanitarian Law Applicable in Armed Conflicts, Geneva (1974-7): Volume VII (Federal Political Department 1978) 81 (India).

54 See, eg, Convention for the Protection of Human Rights and Fundamental Freedoms (European Convention on Human Rights, as amended) (ECHR); International Covenant on Civil and Political Rights (adopted 16 December 1966, entered into force 23 March 1976) 999 UNTS 171 (ICCPR).

55 MT Kamminga and M Scheinin, The Impact of Human Rights Law on General International Law (OUP 2009) 22.

56 Such scholars are extremely varied in their focus and the reasons for their caution: see, eg, A Pellet, “"Human Rightism" and International Law' (2000) 10 Italian Ybk Intl L 3 (doubting that the human rights movement has fundamentally altered the State-centrism of international law); S Marks, The Riddle of All Constitutions: International Law, Democracy and the Critique of Ideology (OUP 2000) (critiquing the emancipatory promise of the so-called 'democratic norm thesis' and the marginalisation of socio-economic rights); A Orakhelashvili, 'The Position of the Individual in International Law' (2000) 31 Cal W Intl LJ 241 (arguing that the emergence of rights and obligations of individuals in international law has not elevated them to the position of international legal persons).

57 See, eg, FL Kirgis, 'Custom on a Sliding Scale' (1987) 81 AJIL 146; T Meron, 'The Geneva Conventions as Customary Law' (1987) 81 AJIL 361; Kamminga and Scheinin (n 55) 7-8 and ch 6; Prosecutor v Kupreškić (Trial Judgment) IT-95-16-T (14 January 2000) [527] and [531] (suggesting that custom can form with scant practice where demanded by principles of humanity). 
international trading system. ${ }^{58}$ Theodor Meron has referred to this trend as the 'humanization of public international law'. 59

This evolution of IHRL has also continued to have an important impact on IHL and, importantly for our purposes, the evolution of the law of non-international armed conflict, following the important step made in 1949. This influence is illustrated clearly in two particular developments: first, the adoption of the Additional Protocols in 1977, and, second, the development of customary law by the ICTY. On the first, IHRL played an important role at the 1974-7 diplomatic conference at which the Protocols were negotiated. Indeed, the work of the UN in the late 1960s on human rights in armed conflict ${ }^{60}$ can be seen as a prelude to the diplomatic conference. ${ }^{61}$ More specifically, the influence of IHRL on that process is illustrated in several ways. First, the provision noted above in Article 1(4) API, regarding wars of national liberation, was heavily influenced by recent developments that had occurred in IHRL and State practice. Thus, during the 1960s and early 1970s, as a result of the decolonisation process, self-determination consolidated into an independent human right. ${ }^{62}$ This fact, together with the representation at the 1974-7 conference of many newlyindependent States and national liberation movements, ${ }^{63}$ led to the elimination of the distinction for a very specific category of non-international armed conflicts, i.e. those involving anti-colonial or national liberation struggles. ${ }^{64}$

Second, and most importantly for present purposes, just as the post-war consolidation of intra-State structures of obligation was relied upon by certain States advocating the adoption of common Article 3, so the continued expansion of IHRL was invoked by a number of delegates at the 1974-7 diplomatic conference as evidence of the increasing role played by international law in protecting individuals vis-à-vis their own State. This served to highlight not only that the historical basis for the marginalisation of non-international armed conflicts was being constantly eroded but that this marginalisation was also inconsistent with the emphasis on individual protection that was becoming so ubiquitous in international law. This line of argument was employed by a number of delegates at the 1974-7 diplomatic conference. For example, during the drafting of APII, the delegate for the Federal Republic of Germany (FRG) argued:

... there had been considerable developments in international law since the drafting of the [UN] Charter and the legal position of the individual had also changed. The Universal Declaration of Human Rights had been adopted by the General Assembly of the United Nations on 10 December 1948, but it was only now becoming clear that the individual had a part to play as a subject of the new legal order ... One result of that development had been a change in the definition

58 Compare, eg, EU Petersmann, 'The WTO Constitution and Human Rights' (2000) 3 J Intl Econ Law 19 and P Alston, 'Resisting the Merger and Acquisition of Human Rights by Trade Law: A Reply to Petersmann' (2002) 13 EJIL 815.

59 Meron (n 43) xv.

60 See, eg, Final Act of the International Conference on Human Rights, UN Doc A/Conf.32/41, 22 April-13 May 1968; UNGA Res 2444 (XXIII), 'Respect for Human Rights in Armed Conflict' (19 December 1968).

61 Sivakumaran (n 4) 44-6 (noting this contribution of the UN).

62 ICCPR (n 54) art 1(1); R Higgins, Problems \& Process: International Law and How We Use It (OUP 1994) 114-5.

63 Sandoz (n 30) xxxiii; Official Records of the Diplomatic Conference on the Reaffirmation and Development of International Humanitarian law Applicable in Armed Conflicts, Geneva (1974-7): Volume I (Federal Political Department 1978) 7 (the 'progressive development and codification of international humanitarian law applicable in armed conflicts is a universal task in which the national liberation movements can contribute positively'); C Ewumbue-Monono, 'Respect for International Humanitarian Law by Armed NonState Actors in Africa' (2006) 88 IRRC 905, 917-8.

64 API (n 12) art 1(4). 
of State sovereignty in international relations. One of the most important limitations on State sovereignty was respect for human rights. ${ }^{65}$

By invoking IHRL in this manner, as evidence of the extension of international law to intraState matters for the purpose of protecting individuals, norms of IHL were then free to move across into non-international armed conflicts and, in so doing, the distinction could be narrowed. Consequently, as with common Article 3, the majority of the provisions of APII were based on the law applicable in international armed conflicts. ${ }^{66}$ Indeed, this was treated as the self-evident means by which to humanise non-international conflicts. ${ }^{67}$ There were exceptions to this, whereby specific rights contained in human rights treaties were drawn on directly in drafting particular provisions in APII. ${ }^{68}$ However, where this was the case, it was done so either for both international and non-international armed conflicts or simply to address a situation unique to non-international conflicts. Importantly, IHRL was not invoked as an alternative to drawing from the rules applicable in international conflicts. ${ }^{69}$

The same influence of IHRL can also be seen in the developments that have occurred in customary international law. Much of this development was recognised, and driven, by the ICTY. ${ }^{70}$ The Appeals Chamber in Prosecutor v Duško Tadić, for example, invoked IHRL in precisely the same manner as the delegate of the FRG at the 1974-7 conference, holding that a number of rules applicable as treaty law only in international conflicts now apply equally, under custom, in non-international armed conflicts. It is worth quoting the judgment at length:

The impetuous development and propagation in the international community of human rights doctrines, particularly after the adoption of the Universal Declaration of Human Rights in 1948, has brought about significant changes in international law ... A State-sovereignty-oriented approach has been gradually supplanted by a human-being-oriented approach ... It follows that in the area of armed conflict the distinction between inter-State wars and civil wars is losing its value as far as human beings are concerned. Why protect civilians from belligerent violence, or ban rape, torture or the wanton destruction of hospitals, churches, museums or private property, as well as proscribe weapons causing unnecessary suffering when two sovereign States are engaged in war, and yet refrain from enacting the same bans or providing the same protection when armed violence has erupted "only" within the territory of a sovereign State?

Again, the evolution of IHRL was invoked as evidence that the historical basis for the distinction between types of conflict had fallen away, allowing for humanitarian concerns to become decisive. ${ }^{72}$ On this basis, the Appeals Chamber concluded that a number of rules of

65 Official Records: Vol VIII (n 53) 220 [29]-[30]. Similarly, see ibid, 223 [46] (Italy); ibid, 218 [18]-[19] (New Zealand); ibid, 222 [40] (Netherlands); ibid, 230 [10] (Argentina).

66 See, eg, Sandoz (n 30) 1369 [4516], 1385 [4565], 1448 [4761] (noting the provenance of arts 4(1), 5 and 13 APII, respectively, in the law of international armed conflict).

67 Sivakumaran (n 4) 64.

68 See, eg, Sandoz (n 30) 1376 [4541] (on art 4(2)(f) APII prohibiting slavery and the slave trade).

69 This is in contrast to the approach adopted by some in modern debates, discussed below under Section III.

70 R Cryer, 'Of Custom, Treaties, Scholars and the Gavel: The Influence of the International Criminal Tribunals on the ICRC Customary Law Study' (2006) 11 JCSL 239, 240; GH Aldrich, 'The Laws of War on Land' (2000) 94 AJIL 42, 61.

71 Tadić (n 17) [97]. Similarly, see Meron (n 43) 4.

72 See also Prosecutor v Delalić et al (Appeals Judgment) IT-96-21-A (20 February 2001) [172]. 
IHL, such as those relating to the means and methods of warfare, had crystallised as custom applicable in non-international armed conflicts. ${ }^{73}$ Once again, therefore, it has been the consistent approach of the ICTY to look to the law of international armed conflict when examining the customary rules applicable in non-international conflicts.

\section{Conclusions}

To sum up the discussion thus far, the above sections have demonstrated the important role played by IHRL in encouraging the development of the law of non-international armed conflict and the latter's resulting convergence with the law applicable in international armed conflicts. Initially, the emergence of IHRL in the aftermath of the Second World War represented the consolidation of intra-State structures of obligation in international law, contributing to the necessary foundations for the adoption of common Article 3. Thereafter, the rapid evolution of IHRL and its emphasis on individual protection vis-à-vis one's own State was relied upon in support of subsequent developments in the law of non-international armed conflict. Importantly, as a result of the way in which IHRL was invoked, these developments have generally drawn on the law applicable in international armed conflicts. The consequence is that IHRL has encouraged the gradual and partial elimination of the distinction in IHL between categories of armed conflict. Indeed, there are few areas in the law of non-international armed conflict that remain untouched by this gradual erosion. ${ }^{74}$

More recently, however, IHRL has had the opposite effect, in certain instances encouraging the preservation of what remains of the distinction between international and non-international armed conflicts. It is to this that we now turn in the following section.

\section{The Preservation of the Distinction Between Categories of ARMed CONFLICT}

In order to complete the picture of the impact of IHRL on IHL's distinction between the two categories of armed conflict, it is necessary to consider recent debates concerning the further development of the law of non-international armed conflict. It will be shown in this section how these debates have been heavily influenced by IHRL, with consequences for the general distinction and its preservation. In particular, IHRL has contributed to the emergence of two opposing schools of thought on the development of the law of non-international armed conflict. I term these schools the 'human rights approach' and the 'humanitarian law approach', so as to reflect their differing views on the appropriate source of rules for noninternational armed conflicts (these are, in many ways, the two extremes at either end of a spectrum). It is important to note that it is not the goal of this section to consider the relative merits of these approaches or to argue whether one or the other might be a more appropriate avenue for the law to follow. Instead, the focus is on the impact that each of these approaches would have on the distinction between international and non-international conflicts in IHL. It will be shown that neither seeks entirely to eliminate this distinction; on the contrary, each relies, for very different reasons, on its preservation, marking a significant change from the traditional influence of IHRL that was explored in the previous section. These two schools of thought will now be discussed in turn.

73 Tadić (n 17) [127].

74 See, eg, Sivakumaran (n 4), especially Part II, demonstrating the large number of rules now applicable in non-international conflicts. Amongst those areas that remain unaffected by this trend, one might note in particular combatant immunity and detention: M Sassòli and LM Olson, 'The Relationship between International Humanitarian Law and Human Rights Law Where it Matters: Admissible Killing and Internment of Fighters in Non-International Armed Conflicts' (2008) 90 IRRC 599. 


\section{A. The human rights approach}

It was noted at the outset that one of the major criticisms of the distinction between international and non-international armed conflicts has been its inconsistency with the humanitarian premise of IHL: by focusing on international conflicts and marginalising noninternational conflicts, IHL has failed sufficiently to protect victims of the latter. As was demonstrated in the previous section, the solution to this problem that traditionally has been adopted both in State practice and jurisprudence is gradually to eliminate the distinction between types of conflict by extending the rules applicable in international conflicts to noninternational conflicts. Indeed, those States that have sought to negotiate the highest level of protection for victims of internal conflicts have advocated the extension of most, if not all, of the rules of IHL. $^{75}$ This has similarly been the approach advanced by a number of commentators. ${ }^{76}$ It was shown that an important driver in these developments was the parallel emergence and consolidation of human rights protections at the international level.

This section will now demonstrate that some recent approaches to the development of the law of non-international armed conflict invoke IHRL in a very different manner than traditionally was the case, with the consequence that what remains of IHL's distinction between categories of conflict would be preserved. It was shown above that during the 1949 and 1974-7 diplomatic conferences, for example, IHRL was invoked as evidence of the consolidation of intra-State structures of obligation in international law and the importance of individual protection vis-à-vis one's own State. This meant that the historical basis for the distinction in IHL could fall away. Certain of the rules previously applicable only in international armed conflicts could then be extended to their non-international counterparts. The manner in which IHRL is invoked in the approaches explored in this section, however, differs significantly from this traditional technique. Here, IHRL is drawn on not as an analogy, justifying the extension of the rules applicable in international armed conflicts, but rather as a source of rules in itself. Thus, certain international bodies and commentators have drawn on IHRL directly to regulate non-international armed conflicts rather than extending the entire corpus of IHL, achieving the goal of protecting victims in such conflicts whilst maintaining the general distinction under humanitarian law. As such, IHRL is now being invoked in a way that would preserve what remains of IHL's distinction, in contrast to the orthodoxy discussed in the previous section. It must be borne in mind that the approaches explored here are relevant to the law of non-international armed conflict both de lege lata and de lege ferenda; this will be demonstrated throughout.

These human rights approaches to the law of non-international armed conflict can be seen particularly clearly in certain practice regarding detention de lege lata. This was the case, for example, in the ICRC's 2005 Study on Customary International Humanitarian Law. Generally, the Study drew on the law of international armed conflict in elaborating the customary rules applicable in non-international conflicts, consistent with the approach explored above. ${ }^{77}$ However, this was not true in all cases, and in certain areas it drew instead on IHRL, leading to different standards applying depending on the character of a given conflict. This was seen, for example, in its Rule 99, which declared that '[a]rbitrary

75 See, eg, Final Record: Vol II-B (n 46) 326 (Soviet Union); Final Record: Vol I (n 52) 47 (ICRC); Official Records of the Diplomatic Conference on the Reaffirmation and Development of International Humanitarian Law Applicable in Armed Conflicts, Geneva (1974-1977): Volume V (Federal Political Department 1978) 91 (Norway); Official Records: Vol VII (n 53) 321-2 (Holy See).

76 See, eg, Crawford (n 9); Mastorodimos (n 20).

77 The ICRC's methodology necessarily pointed it towards mapping of the law of non-international armed conflict on the law of international armed conflict: Sivakumaran (n 4) 58-9. 
deprivation of liberty is prohibited' under custom in both international and non-international conflicts. ${ }^{78}$ In elaborating this rule for international armed conflicts, the ICRC referred, inter alia, to the IHL treaty rules in the Fourth Geneva Convention, ${ }^{79}$ which permit a belligerent power to intern enemy civilians where necessary for reasons of security, subject to the provision of initial and periodic administrative reviews. ${ }^{80}$ The treaty law of non-international armed conflict, however, is silent on the regulation of detention. As a result, in such situations, rather than drawing by analogy from the rules for international armed conflicts found in the Fourth Geneva Convention, the ICRC relied on the more protective IHRL standards alone, concluding, inter alia, that internees in non-international conflicts must be able to challenge the legality of their internment before a court, ${ }^{81}$ a right protected under IHRL but not IHL. ${ }^{82}$ The result is that the rules applicable in international and noninternational conflicts remain different, with different bodies of law regulating each situation.

The same, differentiated approach to the regulation of detention can be seen in the jurisprudence of the Grand Chamber of the European Court of Human Rights. In Al-Jeddav $U K$, the Court examined the legality of Al-Jedda's detention by the UK during the noninternational armed conflict phase of coalition operations in Iraq. ${ }^{83}$ The Court rejected the UK's arguments that relevant Security Council Resolutions authorising internment in similar situations to those found in the Fourth Geneva Convention for international armed conflicts prevailed over Article 5 of the European Convention on Human Rights (ECHR). ${ }^{84}$ Consequently, the Court concluded that Article 5 ECHR alone applied as the relevant legal framework for regulating the UK's detention operations. This is to be contrasted with the Grand Chamber's subsequent approach in Hassan $v U K$, which again concerned a detention by the UK in Iraq, but during the international armed conflict phase. ${ }^{85}$ Here, the Court held that the primary legal framework against which the UK's detention operations in such situations are to be judged is IHL, with its more permissive grounds for detention and review procedures being read into Article 5 ECHR as a matter of treaty interpretation. ${ }^{86}$ The consequence, like that of Rule 99 in the ICRC's Study, is that whilst detention in international armed conflicts is subject in the first place to IHL, detention in non-international armed conflicts, in the absence of relevant IHL treaty rules, remains regulated solely by IHRL, leaving the distinction between the two categories of armed conflict intact. ${ }^{87}$

This approach of the ICRC and the European Court of Human Rights relates to the lex lata of non-international armed conflicts. ${ }^{88}$ That is to say, they are applying IHRL on the basis that those rules, in their view, reflect the sole standards against which the particular State conduct must be judged in such situations, given the silence of IHL in this area. ${ }^{89}$ This

78 Henckaerts and Doswald-Beck, Vol I (n 17) 344.

9 Ibid, 344-6.

80 GCIV (n 5) arts 41-3 and 78.

81 Henckaerts and Doswald-Beck, Vol I (n 17) 350-1.

See, eg, ICCPR (n 54) art 9(4); ECHR (n 54) art 5(4).

83 Al-Jedda v United Kingdom, App No 27021/08, Judgment (Grand Chamber), 7 July 2011.

84 Ibid, [97]-[110].

85 Hassan v United Kingdom, App No 29750/09, Judgment (Grand Chamber), 16 September 2014.

86 Ibid, [96]-[111].

87 Whilst one might argue that the different approach taken in Hassan is simply a result of the UK government having for the first time raised the argument that IHL, rather than the ECHR, is the governing regime, the Court made clear that its approach in that case was restricted to international armed conflicts, leaving its Al-Jedda approach unaffected: ibid, [104].

88 The same approach can be seen in a report by a group of UN Special Rapporteurs with regard to US detention at Guantanamo Bay: UN Commission on Human Rights, 'Situation of Detainees at Guantanamo Bay', E/CN.4/2006/120 (27 February 2006) [19] and [24].

89 In the absence of IHL treaty rules applicable to detention in non-international conflicts, certain commentators similarly adopt this approach: see, eg, N Rodley and M Pollard, The Treatment of Prisoners 
reliance on IHRL over IHL, however, also arises de lege ferenda, and it is argued by certain commentators that the law of non-international armed conflict should continue to be based on IHRL as opposed to drawing by analogy from the law of international armed conflict. Louise Doswald-Beck, for example, takes the view that, with regard to the use of force against members of non-State armed groups, the standards of IHRL can be more appropriate for situations of non-international armed conflict than simply analogising to the rules on targeting in international armed conflicts. ${ }^{90}$ David Kretzmer follows a different line of reasoning, arguing for a gradated approach to the regulation of non-international armed conflicts, with IHRL alone regulating those up to the applicability threshold of APII, ${ }^{91}$ whilst the entire corpus of IHL would then apply to those that meet or surpass that threshold. ${ }^{92}$ What unites these different approaches is their use of IHRL as a direct source of rules for (at least some) non-international armed conflicts, rather than simply proposing the extension of the entire corpus of IHL to all such conflicts. The consequence is to provide for different standards depending on the character of the conflict: in international armed conflicts, the detailed rules of IHL operate, on one view, as the lex specialis and provide the primary standards against which conduct is to be judged; ${ }^{93}$ in non-international armed conflicts, on the other hand, these approaches envisage the application of IHRL as the governing standards, at least for lower intensity non-international conflicts. Whereas the previous section demonstrated that, traditionally, IHRL had been invoked so as to encourage the dissolution of the distinction between categories of conflict in IHL, the approaches explored here invoke IHRL as the direct source of rules, in a manner that would partially preserve what remains of the distinction. ${ }^{94}$

Whether these approaches are more appropriate for the purposes of developing the law than extending the whole corpus of IHL to non-international armed conflicts is beyond the scope of this article. Instead, what is relevant for present purposes is why some now rely on IHRL rather than IHL in proposing how the law applicable to non-international conflicts should develop. The answer lies in the relative protective capacities of the two bodies of law. ${ }^{95}$ Thus, in most areas, IHRL, as it has come to be developed in jurisprudence, provides greater protections to individuals than IHL. ${ }^{96}$ This is, in part, a result of the differing premises

under International Law ( $3^{\text {rd }}$ edn, OUP 2009) 489-91; LM Olson, 'Practical Challenges of Implementing the Complementarity between International Humanitarian and Human Rights Law-Demonstrated by the Procedural Regulation of Internment in Non-International Armed Conflict' (2009) 40 Case W Res J Intl L 437, 454; L Doswald-Beck, Human Rights in Times of Conflict and Terrorism (OUP 2012) 277-9.

90 L Doswald-Beck, 'The Right to Life in Armed Conflict: Does International Humanitarian Law Provide All the Answers?' (2006) 88 IRRC 881, 889-91 and 903-4. For a similar argument regarding targeting, see W Abresch, 'A Human Rights Law of Internal Armed Conflict: The European Court of Human Rights in Chechnya' (2005) 16 EJIL 741.

91 On this see above, text to $\mathrm{n} 14$.

92 Kretzmer ( $\mathrm{n}$ 30). Similarly, with regard to the regulation of the use of force in non-international armed conflict, see C Garraway, “To Kill or Not to Kill?"-Dilemmas on the Use of Force' (2010) 14 JCSL 499, 509-10.

93 On the use of the lex specialis principle by the ICJ in defining the relationship between IHL and IHRL, see below at text to nn 112-13.

94 One might alternatively view some of these approaches, notably Kretzmer's and Garraway's, as eliminating the distinction between international and non-international armed conflicts whilst at the same time raising the threshold for a non-international armed conflict to come into existence, leaving IHRL as the governing regime in a number of situations that currently would constitute non-international armed conflicts. It should also be noted that others have taken a human rights approach to the regulation of all armed conflicts, resulting in more protective, unified rules: see, eg, FF Martin, 'Using International Human Rights Law for Establishing a Unified Use of Force Rule in the Law of Armed Conflict' (2001) 64 Sask L Rev 347.

95 This is noted by Kretzmer (n 30) 24-6

96 T Meron, 'The Humanization of Humanitarian Law' (2000) 94 AJIL 239, 240. See the example below regarding targeting at text to nn 104-08. 
of the two bodies of law. IHRL was conceived as a body of rules to govern 'normal' peacetime situations; its primary function is the protection of the individual vis-à-vis the State, and it was envisaged as having general applicability. ${ }^{97} \mathrm{IHL}$, on the other hand, was developed to regulate a very specific situation, and its rules were consequently subject to different considerations than those of IHRL. ${ }^{98}$ In particular, it is often said that the rules of IHL represent a balance between humanitarian considerations and considerations of military necessity, ${ }^{99}$ a balance not reflected in IHRL. ${ }^{100}$ IHL thus has a permissive element to it, and although IHRL treaties also contain certain permissive aspects, ${ }^{101}$ the unique character of military necessity in IHL, together with the fact that IHRL has had the benefit of development through international jurisprudence, has meant that this permissive feature is much more prevalent in IHL than it is in IHRL. Indeed, certain scholars have argued that this permissive aspect of IHL reveals its true nature. Chris Jochnick and Roger Normand, for example, argue that, whilst humanitarian sentiments were the initial triggers for each successive codification of the laws of war,

... the diplomats who negotiated the laws and the soldiers who implemented them structured a permissive legal regime. Despite the humanitarian rhetoric, military concerns have dictated the substantive content of the laws of war. National governments, conceiving their sovereign interests narrowly, have proven unwilling to accept any restrictions, legal or otherwise, on their ability to deploy the level of military power they deem necessary to uphold national security. ${ }^{102}$

The permissive nature of IHL relative to IHRL was alluded to above with regard to the different approaches under each legal regime concerning the regulation of detention. ${ }^{103}$ It may also be illustrated by comparing the rules on the use of lethal force. Thus, it is generally accepted that IHL permits the lethal targeting of those qualifying as combatants at any time on the basis of that status alone, without the requirement that it actually be necessary in the prevailing circumstances, e.g. for self-defence. ${ }^{104}$ This lack of immunity of combatants from targeting is premised on the presumed threat that is posed by the group, "whether or not he or she personally endangers the lives or interests of the other party to the conflict." 105 Indeed, when the ICRC argued in its 2009 Interpretive Guidance on Direct Participation in Hostilities that the force used against otherwise legitimate targets (including combatants) 'must not exceed what is actually necessary to accomplish a legitimate military purpose in the

97 C Droege, 'Elective Affinities? Human Rights and Humanitarian Law' (2008) 90 IRRC 501, 521.

98 Ibid.

99 M Schmitt, 'Military Necessity and Humanity in International Humanitarian Law: Preserving the Delicate Balance' (2010) 50 Va J Intl L 795.

${ }^{100}$ N Prud'homme, 'Lex Specialis: Oversimplifying a More Complex and Multifaceted Relationship?' (2007) 40 Isr L Rev 356, 361.

101 See, eg, the limitation and derogation clauses found in IHRL treaties: ICCPR (n 54) arts 18(3) and art 4. For a comparison of the permissive roles played by considerations of necessity in IHL and IHRL, see L HillCawthorne, 'The Role of Necessity in International Humanitarian and Human Rights Law' (2014) 47 Isr L Rev 225.

102 C Jochnick and R Normand, 'The Legitimation of Violence: A Critical History of the Laws of War' (1994) 35 Harvard Intl LJ 49, 56. One might contrast this with the more optimistic view of contemporary IHL put forward by Meron (n 96).

103 See discussion above, text to nn 79-82.

104 Dinstein (n 24) 34; G Solis, 'Targeted Killing and the Law of Armed Conflict' (2007) 60 Naval War College Rev 127, 130.

105 D Kretzmer, 'Targeted Killing of Suspected Terrorists: Extra-Judicial Executions or Legitimate Means of Defence?’ (2005) 16 EJIL 171, 190-1. 
prevailing circumstances, ${ }^{106}$ this was heavily criticised by many commentators for its alleged failure accurately to reflect the current lex lata. ${ }^{107}$ This liberal approach to targeting under IHL contrasts starkly with the equivalent rules in IHRL as they have been developed in jurisprudence. There, it is required that the use of lethal force only be employed where it is necessary in the prevailing circumstances for the achievement of a legitimate aim, such as in self-defence, and where proportionate to that aim. ${ }^{108}$ Thus, unlike IHL, under IHRL nobody may be targeted solely on the grounds of status.

IHRL, as developed in case law, thus offers a generally more protective regime than IHL. It is for this reason that there is a preference by some scholars to rely, at least in part, on IHRL as a direct source of rules for developing the law of non-international armed conflict. ${ }^{109}$ In addition, the evolution of IHRL has also fundamentally changed the consequences of eliminating the distinction in IHL between international and non-international conflicts. As David Kretzmer demonstrates when justifying his proposals for developing the law of noninternational armed conflict, whereas historically the assumption was that, absent regulation by IHL, States would entirely be free in the means and methods used to counter an insurgency on their territory, the emergence of IHRL has now changed this. ${ }^{110}$ Although this has been a topic of some dispute in the past, it is now trite to note the mainstream view that IHRL, absent derogation, continues to apply in armed conflict, including non-international conflicts. ${ }^{111}$ Were the distinction between international and non-international conflicts eliminated, the entirety of IHL would then apply alongside IHRL in non-international conflicts, raising the question of how the two bodies of law would interact. The International Court of Justice in its Nuclear Weapons advisory opinion interpreted this relationship for the purposes of the right to life using the lex specialis maxim, whereby the 'open' standards of IHRL are interpreted according to the specialised rules of IHL:

The test of what is an arbitrary deprivation of life ... falls to be determined by the applicable lex specialis, namely, the law applicable in armed conflict which is designed to regulate the conduct of hostilities. Thus whether a particular loss of

106 Interpretive Guidance on the Notion of Direct Participation in Hostilities under International Humanitarian Law (ICRC 2009) section IX. Similar views have been expressed elsewhere: see, eg, JS Pictet, Development and Principles of International Humanitarian Law (Martinus Nijhoff 1985) 75; R Goodman, 'The Power to Kill or Capture Enemy Combatants' (2013) 24 EJIL 819.

107 See, eg, W Hays Parks, 'Part IX of the ICRC's "Direct Participation in Hostilities": No Mandate, No Expertise and Legally Incorrect' (2010) 42 NYU J Intl L \& Pol 769; MN Schmitt, 'The Interpretive Guidance on the Notion of Direct Participation in Hostilities: A Critical Analysis' (2010) 1 Harv Nat Sec J 5, 39; JK Kleffner, 'Section IX of the ICRC Interpretive Guidance on Direct Participation in Hostilities: The End of Jus in Bello Proportionality as We Know It?' (2012) 45 Isr L Rev 35.

108 See, eg, Suarez de Guerrero $v$ Colombia (1982) Communication No R.11/45, UN Doc Supp No 40 (A/37/40) (Human Rights Committee) [13.1]-[13.3] (interpreting art 6(1) ICCPR); McCann and others $v$ United Kingdom, App No 18984/91, 27 September 1995, [145]-[150] (European Court of Human Rights) (interpreting art 2 ECHR); UNGA, Report of the Special Rapporteur on Extrajudicial, Summary or Arbitrary Executions (Christof Heyns), A/68/382, 13 September 2013, [32]-[37].

109 This recognition lies at the heart, for example, of David Kretzmer's approach to the regulation of noninternational armed conflict.

${ }^{110}$ Kretzmer (n 30) 18-21.

111 See, eg, Droege (n 97) 503-9; N Lubell, Extraterritorial Use of Force Against Non-State Actors (OUP, Oxford 2010) 237-40; Legality of the Threat or Use of Nuclear Weapons (Advisory Opinion) [1996] ICJ Rep 226 [25]; Legal Consequences of the Construction of a Wall in the Occupied Palestinian Territory, Advisory Opinion [2004] ICJ Rep 136 [106]; Case Concerning Armed Activities on the Territory of the Congo (DRC $v$ Uganda) [2005] ICJ Rep 116 [216]-[217]. Indeed, those sceptical of the application of human rights law in armed conflict appear to accept it at least for (internal) non-international armed conflicts: see, eg, MJ Dennis, 'Non-Application of Civil and Political Rights Treaties Extraterritorially During Times of International Armed Conflict' (2007) 40 Isr L Rev 453, 455. 
life, through the use of a certain weapon in warfare, is to be considered an arbitrary deprivation of life contrary to Article 6 of the Covenant [on Civil and Political Rights], can only be decided by reference to the law applicable in armed conflict and not deduced from the terms of the Covenant itself. ${ }^{112}$

The consequence of the ICJ's lex specialis approach to the relationship between IHL and IHRL is that, whilst IHRL continues to apply in armed conflict, one enjoys no more substantive protection than otherwise exists under IHL. ${ }^{113}$ As noted above, the rules relating to targeting in IHL are much more permissive than those in IHRL, especially in light of the latter's elaboration through jurisprudence. By virtue of the ICJ's approach, therefore, extending the detailed IHL rules on the conduct of hostilities to non-international conflicts could be invoked as a justification for significantly curtailing the protections already afforded by the applicable rules of IHRL. ${ }^{114}$ Consequently, the long-held view that eliminating the distinction in IHL would improve the protections afforded to victims of non-international conflicts now faces a powerful counterargument, summed up well by Kretzmer:

\begin{abstract}
While the original intention behind extension of IHL to non-international armed conflicts was to enhance the protection granted to potential victims of such conflicts, given the dramatic development of IHRL, categorization of a situation as one of armed conflict [to which IHL would then become applicable] ... may serve to weaken the protection offered to potential victims rather than to strengthen it. ${ }^{115}$
\end{abstract}

Whilst many have raised cogent arguments against such inferences being drawn from the Court's use of the lex specialis maxim, ${ }^{116}$ it is clear that others endorse the notion of IHL as effectively displacing otherwise applicable IHRL. ${ }^{117}$ Indeed, certain commentators are of the view that, by virtue of the extension under custom of many of the rules of IHL to noninternational armed conflicts, they already operate as the lex specialis, requiring that applicable human rights law be interpreted in conformity with the more permissive IHL standards. ${ }^{118}$ The present author is sceptical of these views. First, it is important to note that the ICJ's invocation of the lex specialis maxim is a simple acknowledgment that the adoption of detailed treaty rules on a particular subject might be one relevant factor indicating the common intentions of the States parties when seeking to interpret another, 'open' treaty provision. The lex specialis maxim does not answer finally which rule prevails; rather, it

112 Legality of Nuclear Weapons, ibid, [25]. The Court similarly invoked the lex specialis maxim, albeit in a slightly different manner in Israeli Wall, ibid, [106].

113 D Akande, 'Nuclear Weapons, Unclear Law? Deciphering the Nuclear Weapons Advisory Opinion of the International Court' (1998) 68 BYIL 165, 175

114 Similarly, see Kretzmer (n 30) 23-31.

115 Kretzmer (n 90) 39.

116 See, eg, O Ben-Naftali and Y Shany, 'Living in Denial: The Application of Human Rights in the Occupied Territories' (2003) 37 Isr L Rev 17, 57-8; A Orakhelashvili, 'The Interaction between Human Rights and Humanitarian Law: Fragmentation, Conflict, Parallelism, Or Convergence' (2008) 19 EJIL 161.

117 Dennis (n 111) 482-6; Human Rights Committee, 'Fourth Periodic Report: United States of America', CCPR/C/USA/4, 22 May 2012, [506]-[507].

118 See, e.g., J Pejić, 'Conflict Classification and the Law Applicable to Detention and the Use of Force' in Wilmshurst (n 3) 113 (arguing that the IHL rules on the conduct of hostilities apply in non-international armed conflicts and thus constitute the lex specialis). This is also implied by Sivakumaran (n 4) at 98 ('... it is not immediately clear why international human rights law should regulate non-international armed conflict. Direct regulation of non-international armed conflict through international human rights law is premised on the idea that there is a lack of content and specificity on the part of international humanitarian law ... However, this premise is open to challenge'). 
reminds us of one potential reference point when interpreting treaty provisions in order to help discern the intentions of the States parties. ${ }^{119}$ Other (equally relevant) factors may exist that undermine the claim that human rights standards are affected by applicable rules of IHL. One cannot invoke the lex specialis maxim without, therefore, considering what weight such 'special' rules should have in the interpretive process and why. ${ }^{120}$

Second, the existence of incompatible treaty or customary obligations is not unusual in international law, and reconciliation of such obligations rests principally with the State that has consented to them. ${ }^{121}$ Otherwise, to the extent that reconciliation through consistent interpretation is not possible, the obligations will often simply apply in parallel to the same facts. Indeed, this was the approach of the ICJ in the only contentious case in which it has addressed the relationship between IHL and IHRL, where the ICJ made no explicit reference to the lex specialis maxim and instead simply applied all relevant treaties, both IHL and IHRL, in parallel, finding violations of both regimes based on the same facts. ${ }^{122}$ The need for a workable legal framework is, of course, especially necessary in this area. However, for those human rights standards that are insufficiently 'open' to allow for interpretation consistent with IHL (ie the ICJ's approach in the Nuclear Weapons opinion), States still enjoy the right to derogate under most general human rights treaties, and it is unclear why we should be looking elsewhere for a means to reconcile these diverging obligations. ${ }^{123}$

Based on the above, one should be sceptical of the assumption that more exhaustive regulation of non-international conflicts by IHL necessarily results in IHRL effectively being displaced. ${ }^{124}$ However, as noted above, it is clear that many make this assumption. Indeed, as will be shown in the following section, certain States have utilised the ICJ's approach here for the purpose of arguing that their actions during armed conflict are subject not to the higher standards of IHRL but the lower standards of IHL. It is this risk that explains the approach of the first school of thought to the regulation of non-international armed conflict explored in this section, that is, that IHRL should be drawn on as a direct source of rules. This represents a significant change from the manner in which IHRL was invoked traditionally, as evidence of the expanding scope of international law, so as to encourage the application of the rules applicable in international conflicts to non-international conflicts. The proposals explored here rely on the continued preservation of (what remains of) IHL's distinction, lest the more permissive standards of IHL be invoked as the lex specialis so as to displace inconsistent (more protective) IHRL standards.

${ }^{119}$ I elaborate on this point in detail in L Hill-Cawthorne, 'Just Another Case of Treaty Interpretation? Reconciling Humanitarian Law and Human Rights Law in the ICJ' in M Andenas and E Bjorge (eds), $A$ Farewell to Fragmentation: Reassertion and Convergence in International Law (CUP 2015).

${ }^{120}$ For similar scepticism being applied to the similar principle in art 31(3)(c) of the Vienna Convention on the Law of Treaties (adopted 22 May 1969, entered into force 27 January 1980) 1155 UNTS 331, see Case Concerning Oil Platforms (Islamic Republic of Iran v United States of America) [2003] ICJ Rep 161, Separate Opinion of Judge Higgins. However, the approach of the European Court of Human Rights in Hassan (n 85) at [102]-[107] seems far less sceptical of the reconciliatory power of art 31(3)(c), relying in part on that provision in order to read into art 5 ECHR the IHL detention provisions applicable in international armed conflict.

${ }^{121}$ Nada $v$ Switzerland, App No 10593/08, Judgment (Grand Chamber), 12 September 2012 [197].

${ }^{122}$ DRC v Uganda (n 111) [217]-[220].

${ }^{123}$ I make this point in L Hill-Cawthorne, 'Regulating Non-International Armed Conflicts: A Review Essay of The Law of Non-International Armed Conflict by Sandesh Sivakumaran' (2014) 32 AYBIL (forthcoming). For a similar argument, see M Milanović, 'Norm Conflicts, International Humanitarian Law, and Human Rights Law' in O Ben-Naftali (ed), International Humanitarian Law and International Human Rights Law (OUP 2011).

${ }^{124}$ Although the European Court of Human Rights in Hassan (n 85) at [102]-[107] clearly considered the existence of IHL treaty rules on detention in international armed conflict as important, reading them into art 5 ECHR, it also relied in part on the practice of States: see ibid, [101]. 
There is another side to this, however, which is represented by the second school of thought. This school starts from an entirely different premise to the one discussed here and seeks to apply IHL alone to govern non-international armed conflicts in order to exploit the permissive aspects of that body of law, which, so the argument goes, contains the more appropriate standards for regulating State action in such situations. Certain advocates of this approach nonetheless continue to support the distinction between international and noninternational armed conflicts in IHL.

\section{B. The humanitarian law approach}

The development of the second school of thought, which I term the 'humanitarian law approach', is in many ways a response to the human rights approach discussed above. In short, whereas the emphasis of the human rights approach lies in the desire to achieve the highest protection for victims of non-international armed conflicts, the humanitarian law approach considers IHRL to be an inappropriate regulatory framework in such situations. Thus, certain States and commentators have called for the exclusive regulation of noninternational conflicts by IHL, in order to exploit the more permissive aspects of that regime, which, so the argument goes, are more appropriate standards in such situations. ${ }^{125}$ Importantly for our purposes, certain advocates of this second school of thought, as with the first, do not envisage the complete elimination of the distinction drawn in IHL between international and non-international conflicts. Instead, as will be shown in this section, they draw from the law of international armed conflict with regard to particular permissive rules, whilst leaving many of the protective rules applicable only in international conflicts.

A recent example of this approach can be seen in the practice of certain States in their military operations against transnational non-State armed groups, such as the post-9/11 practice of the US against al-Qaeda and affiliated groups. This practice has raised questions about how to categorise and regulate such operations, ${ }^{126}$ creating something of a deadlock between those advocating a 'law enforcement/IHRL' paradigm, ${ }^{127}$ and those in favour of a 'war/IHL' paradigm. ${ }^{128}$ These post-9/11 debates are, in fact, no more than a specific application of a much older debate regarding the relationship between IHL and IHRL. That traditional debate centred on claims that IHRL formed part of the law of peace and IHL the

${ }^{125}$ F Ni Aolain, 'The No-Gaps Approach to Parallel Application in the Context of the War on Terror' (2007) 40 Isr L Rev 563, 581.

${ }^{126} \mathrm{~K}$ Watkin, 'Controlling the Use of Force: A Role for Human Rights Norms in Contemporary Armed Conflict' (2004) 98 AJIL 1, 5 (noting that transnational conflicts between States and non-State armed groups straddle not only the peacetime/armed conflict paradigms but also the international armed conflict/noninternational armed conflict paradigms).

${ }^{127}$ See, eg, HRC, 'Concluding Observations: United States of America', CCPR/C/US/CO/3/Rev.1, 18 December 2006, [18]; J Fitzpatrick, 'Sovereignty, Territoriality and the Rule of Law' (2002) 25 Hastings Intl \& Comp L Rev 303; J Pejić, ‘Terrorist Acts and Groups: A Role for International Law?’ (2004) 75 BYIL 71, 85-8; ME O'Connell, 'When is a War Not a War? The Myth of the Global War on Terror' (2005) 12 ILSA J Intl \& Comp L 535.

${ }^{128}$ See, eg, JB Bellinger III, Legal Advisor to the US Department of State, 'Legal Issues in the War on Terrorism', Speech at the London School of Economics \& Political Science (31 October 2006); 'Respondents' Memorandum Regarding the Government's Detention Authority Relative to Detainees Held at Guantanamo Bay', In Re: Guantanamo Bay Detainee Litigation, Misc No 08-442 (TFH) (DDC 13 March 2009) 1; WK Lietzau, 'Detention of Terrorists in the Twenty-first Century' in K Watkin and AJ Norris (eds), NonInternational Armed Conflict in the Twenty-first Century (International Law Studies Volume 88, Naval War College, Newport 2012) 324-8; TL Hemingway, 'Wartime Detention of Enemy Combatants: What If There Were a War and No One Could be Detained Without an Attorney?' (2006) 34 Denver J Intl L \& Policy 63. 
law of war, maintaining the conceptual and practical separability of the two regimes. ${ }^{129}$ This general debate has since faded with the emerging consensus that IHRL prima facie continues to apply in situations of armed conflict, operating alongside IHL. ${ }^{130}$ The post-9/11 practice, however, seems to have resurrected the old debates in particular cases.

This practice relating to conflicts between States and transnational non-State groups is important for our purposes as certain States qualify these as independent non-international armed conflicts. This is the case, for example, with regard to the US' view of its military operations against al-Qaeda, which both the judiciary and the government consider to constitute a global non-international armed conflict, given that it involves hostilities between a State and non-State armed group. ${ }^{131}$ Clauss Kreß has shown more generally how recent State practice supports the application of the law of non-international armed conflict in situations involving transnational non-State groups. ${ }^{132}$ This practice represents a significant change from the past, when it was common for States to reject the view that a particular situation had reached the level of a non-international armed conflict, in order to avoid being bound by the restrictions in common Article 3 and seen to be losing control over their domestic affairs. ${ }^{133}$ However, as David Kretzmer has cogently argued, in light of the development of IHRL and, more specifically, the emerging consensus that those rules continue to apply in armed conflict, States now have an interest in a situation being governed by the more permissive rules of IHL. ${ }^{134}$ As noted, given the ICJ's view that, at least for certain rules, IHRL must be interpreted in accordance with IHL as the lex specialis, applying the latter could allow States to exploit its more permissive rules by arguing that they effectively displace the protections afforded by the stricter IHRL rules. ${ }^{135}$ Ironically, this is in part a consequence of the gradual elimination of the distinction between international and non-international conflicts, itself a result of the humanising influence of human rights law on IHL. ${ }^{136}$ Indeed, it was also noted above that the gradual extension of IHL to non-international armed conflicts has led some to argue that IHL now operates in many areas, such as targeting, as the lex specialis in such situations. ${ }^{137}$ On this view, the conduct of States in noninternational conflicts is to be judged according to the more permissive standards of IHL, rather than the default human rights standards. Whether one shares this view or not, it is clear

129 GIAD Draper, 'The Relationship between the Human Rights Regime and the Law of Armed Conflicts' (1971) 1 Isr Ybk Human Rights 191, 191-6; K Suter, 'An Inquiry into the Meaning of the Phrase "Human Rights in Armed Conflicts"” (1976) 15 Revue de Droit Pénal Militaire et de Droit de la Guerre 393.

${ }^{130}$ See references above at $\mathrm{n} 111$.

131 On the US courts' view, see Gherebi v Obama, 609 F Supp $2 d 43$ (DDC 2009) 57, fn 8; Hamlily $v$ Obama, 616 F Supp 2d 63 (DDC 2009) 73; LM Olson, 'Guantánamo Habeas Review: Are the D.C. District Court's Decisions Consistent with IHL Internment Standards’ (2009) 42 Case W Res J Intl L 197, at 198 (fn 7). On the government's view, see US Department of Justice White Paper, 'Lawfulness of a Lethal Operation Directed Against a U.S. Citizen Who is a Senior Operational Leader of Al-Qa'ida or An Associated Force' (undated; made public on 4 February 2013) 3. Whether this is the correct characterisation of conflicts between States and transnational non-State armed groups is beyond the scope of this article: on this, compare Akande ( $\mathrm{n}$ 8) 70-9 and N Lubell and N Derejko, 'A Global Battlefield? Drones and the Geographical Scope of Armed Conflict' (2013) 11 JICJ 65, 79-80.

${ }^{132} \mathrm{C}$ Kreß, 'Some Reflections on the International Legal Framework Governing Transnational Armed Conflicts' (2010) 15 JCSL 245, 258-61.

${ }^{133} \mathrm{Ni}$ Aolain (n 125) 581-2; Lubell (n 111) 243.

134 Kretzmer (n 30) 23-31.

135 See, eg 'United States Responses to Selected Recommendations of the Human Rights Committee' (US State Department, 10 October 2007) <www.state.gov/documents/organization/100845.pdf>; Dennis (n 111). That this is a potential consequence of the ICJ's treatment of IHL as the lex specialis to IHRL (whether in general or only with respect to specific norms) was discussed above, at text to nn 112-123.

${ }^{136}$ See discussion throughout section II above.

137 See, e.g., Pejic (n 118) 113. 
that States have an advantage in a particular situation being governed by IHL. ${ }^{138}$ In addition, the traditional concern of States that applying IHL in a non-international armed conflict reflected an acknowledgment that they no longer have control over their territory does not apply in the case of extra-territorial military operations.

This advantage for States in having their conduct in non-international armed conflicts regulated exclusively by IHL is augmented by the fact that certain of the protective rules of IHL, such as combatant immunity and prisoner of war (POW) status, remain inapplicable in non-international armed conflicts. ${ }^{139}$ Consequently, the government is able to treat non-State fighters as common criminals and prosecute them for their mere participation in hostilities. ${ }^{140}$ There is, therefore, not only an incentive for States to advocate an 'IHL model' for the regulation of non-international armed conflicts, and to argue that the permissive aspects of that regime then become the governing standards, but there also remains a significant advantage for States in preserving the distinction between international and non-international conflicts with regard to many of the protective rules.

This tendency to differentiate between the permissive and protective aspects of IHL can be seen in US detention practices in the context of its conflict with al-Qaeda. ${ }^{141}$ Here, the US has referred to a general 'law of war' right to detain enemy fighters in any armed conflict for the duration of hostilities. ${ }^{142}$ It is true that the law of international armed conflict explicitly authorises the internment of both enemy forces as POWs for the duration of hostilities, ${ }^{143}$ as well as enemy civilians for so long as they pose such a threat to State security as to necessitate internment. ${ }^{144}$ This power of internment is intimately tied up with the relative statuses recognised by the law of international armed conflict. ${ }^{145}$ However, IHL applicable in non-international armed conflicts neither confers a legal basis to intern nor regulates internment as such; these matters are instead left to domestic law (and IHRL). ${ }^{146}$ Given this

${ }^{138} \mathrm{Kre} ß$ (n 132) 260-1 ('... for States that are faced by a non-State armed attack, the resort to the armed conflict model offers the advantage of applying, as the lex specialis, a targeting and detention regime that is appreciably more permissive than that under international human rights law').

139 Henckaerts and Doswald-Beck, Vol I (n 17) 12-13; Kretzmer (n 30) 36

${ }^{140}$ H Lauterpacht, Oppenheim's International Law, A Treatise: Volume II, Disputes, War and Neutrality $\left(7^{\text {th }}\right.$ edn, Longhams 1952) 211; JS Pictet (ed), Commentary to Geneva Convention III Relative to the Treatment of Prisoners of War (ICRC 1960) 40; Crawford (n 9) 68-76.

141 J Fitzpatrick, 'Speaking Law to Power: The War Against Terrorism and Human Rights' (2003) 14 EJIL 241, 249 ('[i]n essence, the United States has made a claim of 'instant custom', enabling it to exercise extraordinary powers related to international armed conflict, but without any defined protections for its non-state enemies').

${ }^{142}$ This claim has been made by the Obama Administration in the Guantanamo habeas corpus litigation: 'Respondents' Memorandum' (n 128) 5-6 ('... longstanding U.S. jurisprudence, as well as law-of-war principles, recognize that members of enemy forces can be detained even if "they have not actually committed or attempted to commit any act of depredation or entered the theatre or zone of active military operations", (citations omitted)); Lietzau (n 128) 324 ('[f]undamental to understanding U.S. detention policy over the past decade is the comprehension that authority for detention flows from the nature of warfare and the law of war that regulates it').

143 GCIII (n 5) art 21

144 GCIV (n 5) arts 42-3 \& 78

145 Thus, art 21 GCIII permits only internment of those qualifying as combatants, which falls to be determined by art 4 GCIII. Similarly, the right to intern enemy civilians under GCIV is conditional on GCIV applying to the particular individual, which falls to be determined by art 4 GCIV.

${ }^{146}$ See the recent UK case of Serdar Mohammed v Ministry of Defence [2014] EWHC 1369 (QB) (at the time of writing this case is being appealed to the Court of Appeal). Supporting this, see also UN Commission on Human Rights, 'Report of the Working Group on Arbitrary Detention', E/CN.4/2006/7, 12 December 2005, [72]; G Rona, 'An Appraisal of US Practice Relating to "Enemy Combatants" (2007) 10 YIHL 232, 241; AS Deeks, 'Administrative Detention in Armed Conflict' (2009) 40 Case W Res J Intl L 403, 404-5; LM Olson, 'Practical Challenges of Implementing the Complementarity between International Humanitarian and Human Rights Law-Demonstrated by the Procedural Regulation of Internment in Non-International Armed Conflict' 
absence of regulation in IHL, the US draws on what it sees as 'principles' of the law of international armed conflict governing internment and extends these to non-international armed conflicts. ${ }^{147}$ Importantly, however, this practice of analogising to the law of international armed conflict seems only to extend to the permissive rules of IHL; in particular, although the US argues that it may detain enemy fighters in its conflict with alQaeda (which, it was noted above, is treated by the US as a non-international armed conflict) on the same basis as combatants in international armed conflicts, it does not suggest that such fighters might be entitled to the protections afforded to combatants and POWs. ${ }^{48}$

This approach, therefore, seeks the elimination of the distinction between international and non-international armed conflicts with regard only to the permissive rules of IHL (those granting to States certain powers which would not be permitted in peacetime), whilst preserving the distinction for the purpose of the protective rules (those that limit the power of States). Insofar as IHL applicable in international armed conflicts is concerned, such a development would profoundly alter the structure of that regime, which premises the applicability of its permissive rules and protective rules on status: either one is a combatant, and thus subject to internment as a POW and protected by the large number of rules governing POW treatment in GCIII, or one is a civilian, and can only be interned where GCIV applies and where the conditions found therein governing civilian internment are met; where one is so detainable under GCIV, one necessarily enjoys the protections afforded by that treaty. ${ }^{149}$ The right to detain under IHL thus flows from the initial fact that the relevant Convention, with its permissive and protective rules, applies to the individual in question. Drawing solely from the permissive rules applicable in international armed conflicts and applying these by analogy to non-international conflicts without the corresponding protective rules distorts this status-based structure and could result in false positives, given the absence of objectively identifiable 'combatants' who could be targeted and/or interned on the basis of their status alone. ${ }^{150}$

Importantly, extending the permissive rules of IHL to non-international conflicts without the corresponding protective rules is, in fact, precisely the opposite approach which historically has been taken in developing the law of non-international armed conflict. As Sandesh Sivakumaran notes, 'the law of non-international armed conflict does not provide the parties to the conflict with a right to undertake certain actions. Rather, it prohibits certain actions and regulates other conduct should the parties choose to engage in particular endeavours'. ${ }^{151}$ Thus, whilst IHL applicable in non-international conflicts recognises, for example, that the parties to a conflict will intern and use lethal force, it does not provide a legal basis for such actions; rather, it merely accepts that they occur and, without prohibiting, seeks to regulate them. ${ }^{152}$ This is, of course, reflective of the nature of IHL as a legal regime,

(2009) 40 Case W Res J Intl L 437, 452; P Rowe, 'Is There a Right to Detain Civilians by Foreign Armed Forces During a Non-International Armed Conflict?' (2011) 61 ICLQ 697.

147 See above at n 142 .

148 The non-extension of the protections of IHL to Taliban and al-Qaeda detainees has, of course, been the subject of much debate: on the initial refusal, see The White House, 'Memorandum: Humane Treatment of al Qaeda and Taliban Detainees' (7 February 2002), reprinted in KJ Greenberg and JL Dratel (eds), The Torture Papers: The Road to Abu Ghraib (CUP 2005) 134. For a critique of that position, see L Vierucci, 'Prisoners of War or Protected Persons Qua Unlawful Combatants? The Judicial Safeguards to Which Guantanamo Bay Detainees are Entitled' (2003) 1 JICJ 284.

149 This is subject to the derogation provision found in GCIV (n 5) art 5. The provisions of GCIV from which derogation is permissible under art 5 are, however, very limited: D Jinks, 'The Declining Significance of POW Status' (2004) 45 Harvard Intl LJ 367, 387-93.

${ }^{150}$ Interpretive Guidance (n 106) 32-3.

151 Sivakumaran (n 4) 71. Similarly see Rowe (n 146) 702.

152 For example, by prohibiting the targeting of civilians (APII (n 13) art 13(2)) and the inhumane treatment of detainees (APII (n 13) art 5(3)). 
which regulates all aspects of armed conflict without affecting its legality as a matter of the ius ad bellum. ${ }^{153}$ Any legal bases for particular actions, such as detention, in non-international armed conflicts must, therefore, come from another source, principally domestic law. Indeed, the reason for this is clear: given that IHL applies equally to all parties to a non-international armed conflict, ${ }^{154}$ were IHL to provide legal authority to detain in such situations, for example, that legal authority would (presumably) apply equally to non-State armed groups, a result which States have consistently refused to accept. ${ }^{155}$ The practice referred to above of drawing on permissive rules of IHL to the exclusion of protective rules is entirely at odds with the way in which the law of non-international armed conflict has, thus far, developed.

Before concluding, it must be noted that the approaches explored in this section are very closely related to the debate on the existence of a third category of persons in IHL, alongside those of combatant and civilian. It was the view of the Bush Administration that non-State fighters in its conflict with al-Qaeda constituted 'unlawful/enemy combatants', targetable and detainable on the same basis as combatants under the law of international armed conflict and yet not entitled to combatant or POW status. ${ }^{156}$ This view has been heavily criticised for both its legal and ethical shortcomings. ${ }^{157}$ Indeed, State practice, much of which has been in response to US detentions, similarly confirms the non-existence of this alleged third category. ${ }^{158}$ Thus, as Emily Crawford notes, "[g]iven the almost uniform resistance to US attempts to proclaim a "Geneva" status of "unlawful enemy combatant", it is doubtful such a legal category exists. ${ }^{, 159}$ Although the Obama Administration has rejected the designation 'unlawful/enemy combatant', it appears to remain the US' approach to extend the permissive rules on detention in international armed conflicts to its conflict with al-Qaeda, whilst excluding the protective rules. ${ }^{160}$

\section{Conclusions on the two schools of thought}

The above sections have demonstrated how the development of IHRL has encouraged the emergence of two schools of thought on the law of non-international armed conflict. Section $3 \mathrm{~A}$ illustrated how those seeking the highest level of protection of victims of such conflicts no longer advocate eliminating the distinction in IHL between types of conflict but instead seek to apply the more protective rules of IHRL to govern particular conduct in these situations; indeed, these arguments rely on the preservation of what remains of the distinction between the two categories of armed conflict so as to avoid lex specialis-based arguments

153 Dinstein (n 24) 3-4.

${ }^{154}$ C Greenwood, 'Scope of Application of Humanitarian Law' in D Fleck (ed), The Handbook of International Humanitarian Law ( $2^{\text {nd }}$ edn, OUP 2008) 56.

155 Serdar Mohammed (n 146) [245]. A new customary rule creating a legal basis for particular action could, of course, crystallise that applied only to States and not also non-State armed groups, but given the importance of equality of obligation in IHL, it seems reasonable for there to be a presumption that any such rule would bind all parties, rebuttable by reference to contrary practice and opinio iuris.

156 The White House, 'Memorandum: Humane Treatment of al Qaeda and Taliban Detainees' (n 148) [2(d)]; Crawford (n 9) 56-61.

157 See, eg, Vierucci (n 148); K Dörmann, "The Legal Situation of "Unlawful/Unprivileged Combatants"” (2003) 85 IRRC 45; Jinks (n 149) 381-6; M Sassòli, 'The Status of Persons Held in Guantánamo under International Humanitarian Law' (2004) 2 JICJ 96, 100-02.

${ }_{158}$ See, eg, HCJ 769/02, Public Committee Against Torture in Israel et al $v$ The Government of Israel et al, 57(6) PD 285 (Israel Supreme Court) [26]-[28]; PC Tange, 'Netherlands State Practice for the Parliamentary Year 2004-2005' (2006) 37 NYIL 233, 335-7; UK Ministry of Defence, Joint Doctrine Publication 1-10: Captured Persons (CPERS) (2 ${ }^{\text {nd }}$ edn, Ministry of Defence 2011) 1-12 [141].

159 Crawford (n 9) 60.

160 JB Bellinger III and VM Padmanabhan, 'Detention Operations in Contemporary Conflicts: Four Challenges for the Geneva Conventions and Other Existing Law’ (2011) 105 AJIL 201, 217 (fn 79). 
leading to the more permissive IHL rules undermining otherwise applicable human rights standards. Section 3B then explored a second school of thought that has emerged in light of the application of IHRL to armed conflicts. This school takes the view that IHL is the more suitable body of law for regulating non-international conflicts. Moreover, whilst those in this school analogise to the rules applicable in international armed conflicts, section 3B focused on those that do so with regard only to the permissive rules of IHL, preserving the legal distinction between types of conflict for the purposes of certain protective rules. Notwithstanding the difference between these two schools of thought, both rely in part on the preservation of IHL's distinction between international and non-international conflicts.

This recent influence of IHRL is clearly at odds with its influence discussed in section 2 , where it was shown that historically IHRL had encouraged the gradual elimination of the distinction in IHL. This changing influence of IHRL is explained by the context surrounding the various developments in the law of non-international armed conflict. Thus, as explained at the outset, classical international law concerned itself principally with inter-State relations, with internal matters, including civil wars, generally being excluded. This was reflected in the debates leading to the adoption of common Article 3, the latter provision transgressing this traditionally restricted focus of public international law. The emerging international human rights norms at this time, also reflecting the move beyond primarily inter-State matters, were too embryonic for any serious debate to be had on their applicability during armed conflict. ${ }^{161}$ In consequence, the manner in which these developments in IHRL were invoked was generally limited to their use as evidence of the consolidation of intra-State structures of obligation into international law, thereby undermining the historical basis for the marginalisation of non-international conflicts in IHL. It followed that many of the rules applicable in international armed conflicts could then be extended to their non-international counterparts, thus reducing the effects of the distinction in IHL.

As IHRL developed, however, the context changed, with a consensus emerging that the human rights obligations of States continue to apply in situations of armed conflict, especially non-international conflicts. With this changing context, IHRL could now be invoked as a direct source of rules for the regulation of non-international armed conflicts, and their more protective nature meant that those that had long argued for the better protection of victims of internal conflicts could now call for the exclusive application of this body of rules. Importantly, to avoid claims that these higher standards of IHRL were displaced by IHL, the general distinction between categories of conflict had to be preserved. At the same time, however, the emerging consensus regarding the continued applicability of IHRL in times of armed conflict has led others to argue in favour of the exclusive regulation of noninternational conflicts by IHL as the lex specialis. Once again, many of those supporting this approach consider that IHL's distinction between categories of conflict should be preserved with regard to certain protective rules, including those granting combatant and POW status.

\section{CONCLUDING REMARKS}

Whilst most accounts of the distinction between international and non-international armed conflict focus on the consequences of the distinction, this article has approached the subject from a different angle, constructing a narrative of its evolution within the context of the emergence of IHRL. By examining the development over time of IHL's distinction between categories of conflict, and considering its relationship to other developments in international law, it is hoped that this article has offered a richer understanding of this structural feature of

161 That is not, however, to suggest that human rights treaties were not envisaged as relevant in armed conflict: M Milanović, 'Extraterritorial Derogations from Human Rights Treaties in Armed Conflict' in N Bhuta (ed), Collected Courses of the Academy of European Law (OUP, forthcoming). 
IHL. In so doing, it has been made clear that the evolution of the bifurcation of armed conflict by IHL is closely linked with those debates regarding the relationship between that body of law and IHRL.

It is also hoped that this article has contributed to an understanding of some of the recent debates regarding the development of the law of non-international armed conflict, enabling us to move forward in this area. It was noted that the two schools of thought explored in section III are, in reality, extremes on the spectrum of possibilities for how the law of non-international armed conflict might now develop. Many authors fall between the two, arguing for an approach that draws on principles of both IHL and IHRL. ${ }^{162}$ It is submitted that this is the correct approach to take, for any successful discussion of this issue must avoid the intractable IHRL/IHL-paradigm debate. Indeed, it was noted above that the default legal position under existing law (ie absent derogation and other possible means of reconciliation) must be that both IHL and IHRL obligations apply in parallel to the same facts; in order not to be in breach of any obligation, the State must then adhere to the more demanding standard (ie IHRL). ${ }^{163}$ The present author has argued elsewhere that this current state of the law of non-international armed conflict should not be replaced with a new IHL treaty but should instead be built upon, relying on IHRL as the default legal framework regulating State actions, with the possibility of derogation where that framework becomes inappropriate based on the exigencies of the situation; where derogation does take place, a specially-developed IHL regime for non-international armed conflicts would then help to define the minimum standards below which no conduct may fall. ${ }^{164}$ Such an IHL regime would also be necessary in order to address the lack of rules that would otherwise bind the non-State armed group party to the conflict.

In this sense, both IHL and IHRL have important roles to play in any future law of noninternational armed conflict. The artificial boundaries established by legal categories such as 'international armed conflict', 'non-international armed conflict' and other 'situations of internal disturbances and tensions', should not be determinative of the applicable norms. Instead, the starting point might more usefully be conceived in terms of a consideration of how different situations (regardless of their legal characterisation) might be regulated according to the highest standard of individual protection possible, which will involve a combination of rules drawn from both IHL and IHRL.

162 See, eg, Droege (n 97) 536-7; Prud'homme (n 100) 386-93. On the importance more generally of both IHL and IHRL for the law of non-international armed conflict, see S Sivakumaran, 'Re-Envisaging the International Law of Internal Armed Conflict' (2011) 22 EJIL 219.

${ }^{163}$ See above at nn 118-23.

164 Hill-Cawthorne (n 101). 